\title{
POSISI PEREMPUAN DALAM INJIL LUKAS: Sebuah Kajian dengan Perspektif Honor and Shame Melalui Kisah Elisabet*
}

\author{
Hana** $^{* *}$
}

\begin{abstract}
The number of female figures who appear in Luke's gospel behind a social context that places women in a lower position than men, raises questions about the position of women in Luke's gospel. This article aims to explore the woman in Luke's gospel through the story of Elizabeth. Because the issue of women's position related to social status, the analysis in this study will be based on the perspective of honor and shame with symbolic methods in cultural anthropology as the methodology. The results of this analysis show a positive and significant position for women in the Gospel of Luke. This is shown through the symbols of honor embedded in Elizabeth, as well as her significant and prominent role. Even Elizabeth is shown to be in a much more positive position than her husband, Zacharias. Elizabeth shows that women, like men, can play an important role as patrons, witnesses, and prophets. The way Luke positions Elizabeth indicates that there is an elevation of honor for women to an equal position with men.
\end{abstract}

Keywords: honor and shame, cultural anthropology, Elizabeth, women's position, the Gospel of Luke

Abstrak: Banyaknya tokoh perempuan yang dimunculkan di Injil Lukas di balik konteks sosial yang menempatkan perempuan pada posisi yang lebih rendah daripada laki-laki, menimbulkan pertanyaan mengenai posisi perempuan dalam Injil Lukas. Artikel ini bertujuan

* Artikel ini merupakan bagian dari tesis pada program studi Magister Teologi yang telah diuji di Sekolah Tinggi Teologi Amanat Agung.

** Penulis adalah pengajar di sekolah Methodist 3 Medan, Sumatera Utara. Penulis dapat dihubungi melalui email: hanashi77@yahoo.com. 
untuk mengeksplorasi posisi perempuan dalam Injil Lukas melalui kisah Elisabet. Mengingat isu tentang posisi perempuan berhubungan dengan status sosial, maka analisis dalam penelitian ini akan didasarkan pada perspektif honor and shame dengan metode simbolik dalam antropologi budaya sebagai metodologinya. Hasil dari analisis ini memperlihatkan posisi yang positif dan signifikan bagi perempuan dalam Injil Lukas. Hal ini diperlihatkan melalui simbolsimbol kehormatan yang disematkan kepada Elisabet, serta perannya yang terlihat signifikan dan menonjol. Bahkan Elisabet diperlihatkan pada posisi yang jauh lebih positif daripada Zakharia, suaminya. Elisabet memperlihatkan bahwa perempuan, seperti juga laki-laki, dapat berperan penting sebagai patron, saksi, dan penyampai nubuat. Cara Lukas memosisikan Elisabet ini mengindikasikan adanya pengangkatan kehormatan perempuan pada posisi yang setara dengan laki-laki.

Kata-kata Kunci: honor and shame, antropologi budaya, Elisabet, posisi perempuan, Injil Lukas.

\section{Pendahuluan}

Konteks sosial pada abad pertama di Mediterania menempatkan perempuan sebagai the second sex yang entitasnya tidak berdiri sendiri melainkan tertanam di dalam identitas dan kehormatan dari laki-laki. ${ }^{1}$ Dunia perempuan dibatasi hanya di ruang privat, yakni di dalam rumah, serta di sumur dan pasar yang merupakan ekstensi dari ruang privat. $^{2}$ Dengan demikian, perempuan sebaiknya tidak meninggalkan rumah dan

1. David A. deSilva, Honor, Patronage, Kinship \& Purity: Unlocking New Testament Culture (Downers Grove: IVP Academic, 2000), 34.

2. deSilva, Honor, Patronage, Kinship \& Purity, 33. 
dituntut untuk tidak berada di ruang publik tanpa laki-laki. ${ }^{3}$ Bahkan literatur yang hanya menarasikan pertemuan perempuan tanpa kehadiran karakter laki-laki di dalamnya bukanlah sesuatu yang lazim pada masa itu. ${ }^{4}$

Mengingat konteks sosial yang menempatkan perempuan pada posisi yang lebih rendah daripada laki-laki ini, menimbulkan pertanyaan mengenai maksud Lukas menampilkan perempuan dalam jumlah yang jauh lebih besar dibandingkan penulis PB lainnya. ${ }^{5}$ Apakah melalui narasinya yang banyak menghadirkan perempuan di dalamnya, Lukas hendak memosisikan perempuan dalam posisi yang positif -yakni dihormati, dijunjung tinggi, diakui keberadaan dan kompetensinya ${ }^{6}$ - atau sebaliknya, perempuan ditempatkan pada posisi yang negative-yakni

3. Mary Evans mengutip pendapat Philo yang mengatakan, "women are best suited to the indoor life which never strays from the house" (Mary J. Evans, Woman in the Bible: An Overview of All the Crucial Passages on Women's Roles [Downers Grove: Intervarsity Press, 1984], 34).

4. Richard Bauckham bahkan menyebut narasi tentang pertemuan dan komunikasi antar perempuan tanpa kehadiran karakter laki-laki merupakan narasi gynocentric, yakni narasi yang mengandung perspektif perempuan di dalamnya (Richard Bauckham, Gospel Women: Studies of the Named Women in the Gospels [Grand Rapids: Eerdmans, 2002], 51).

5. Turid Karlsen Seim mengungkapkan besarnya jumlah perempuan yang ditampilkan di Injil Lukas dengan menyatakan, "The Gospel of Luke features women in greater number than any other NT writing, including the Acts of the Apostles. As many as forty two passages are concerned with women or with motifs that might be labelled as female-which is more than the other Gospels, even when taking into account their length" (Turid Karlsen Seim, "Feminist Criticism," dalam Methods for Luke, ed. Joel B. Green [New York: Cambridge University Press, 2010], 57).

6. KBBI mengartikan "kompetensi" sebagai "kewenangan (kekuasaan) untuk menentukan (memutuskan sesuatu)." 
dihina, direndahkan, dibatasi dan tidak diakui keberadaan serta kompetensinya.

Salah satu pendekatan yang dapat digunakan dalam menjawab pertanyaan ini adalah pendekatan melalui studi antropologi budaya. Metodologi dengan antropologi budaya merupakan metodologi yang dapat mengeksplorasi kondisi sosial dan budaya yang ada pada sebuah masyarakat, termasuk isu gender di dalamnya. Dengan demikian, isu tentang posisi perempuan yang merupakan isu yang berkaitan dengan status dan stratifikasi sosial dapat dianalisis melalui metodologi ini.

Adapun tujuan dari penulisan artikel ini adalah untuk mengeksplorasi posisi perempuan dalam Injil Lukas serta signifikansi dari posisi ini. Mengingat keterbatasan halaman dalam penulisan artikel ini, maka tokoh perempuan yang akan dianalisis di artikel hanyalah Elisabet. Elisabet merupakan perempuan yang dimunculkan pertama kali oleh Lukas, dan kondisi Elisabet yang mandul merupakan sebuah kondisi yang bersinggungan dengan isu status sosial pada masa itu. Kisah Elisabet juga memperlihatkan "pola berpasangan," yakni pola yang memasangkan kisah mengenai perempuan dengan kisah mengenai laki-laki. Pola berpasangan ini dapat menjadi bahan perbandingan antara posisi laki-laki dan perempuan. Selain itu, "prinsip pembalikan" atau role reversal yang menjadi ciri khas penulisan Lukas juga diperlihatkan dalam kisah Elisabet. Beberapa alasan di atas inilah yang menjadikan Elisabet sebagai tokoh perempuan yang dapat digunakan untuk mewakili penelitian mengenai posisi perempuan dalam Injil Lukas. 
Kisah yang dinarasikan oleh Lukas tentang Elisabet dan cara Lukas menarasikannya dapat memperlihatkan posisi Elisabet dalam Injil Lukas. Hal ini dapat diteliti melalui pendekatan model simbolik dalam antropologi budaya. Penelitian melalui model simbolik ini secara khusus menggunakan sistem nilai honor and shame sebagai dasar perspektifnya.

\section{Model Simbolik dengan Perspektif Sistem Nilai Honor and Shame}

Antropologi adalah ilmu yang mempelajari sifat-sifat manusia sebagai makhluk biologis dan makhluk sosial. ${ }^{7}$ Antropologi budaya mempelajari perbedaan-perbedaan gender yang telah dibakukan dan dilembagakan secara sosial dan budaya dalam suatu masyarakat, termasuk ketimpangan dalam hal kedudukan dan kekuasaan berdasarkan gender. $^{8}$ Karena itu, pendekatan antropologi budaya ini sangat sesuai untuk menguraikan isu tentang gender, yakni tentang posisi perempuan dalam Injil ini.

Salah satu sistem nilai bentukan dari kondisi sosial dan budaya masyarakat Mediterania abad pertama yang dapat digunakan untuk "membaca" isu tentang gender -sebagaimana yang diteliti dalam studi antropologi- adalah sistem nilai honor and shame. Sistem nilai tentang kelayakan/kehormatan seseorang secara sosial ini merupakan perspektif yang sesuai untuk "membaca" bagaimana masyarakat Mediterania abad pertama memosisikan perempuan. Melalui pendekatan model simbolik

7. T. O. Ihromi, "Kata Pengantar" dalam Pokok-Pokok Antropologi Budaya (Jakarta: Pustaka Obor, 2013), ix.

8. Thomas Hylland Eriksen, Antropologi Sosial dan Budaya: Sebuah Pengantar (Maumere: Ledalero, 2009), 213. 
dalam antropologi budaya, kehormatan seseorang dapat dinilai berdasarkan simbol-simbol yang disematkan kepadanya. Simbol adalah hal-hal (orang, benda atau peristiwa) yang memiliki makna dan nilai-nilai yang melekat di dalamnya, sehingga dapat membangun suasana hati dan motivasi yang kuat, meresap dan tahan lama dalam diri seseorang. ${ }^{9}$

Model simbolik adalah model yang menganalisis simbol-simbol yang menyusun sistem sosial, dengan pemahaman bahwa perilaku manusia secara individu maupun kelompok diatur oleh makna simbolik yang melekat pada objek (orang, benda dan peristiwa) yang dihargai secara sosial. ${ }^{10}$ Adapun simbol-simbol yang menandai kehormatan seseorang seringkali didasarkan pada status gender, kekuasaan dan agama yang melekat pada diri seseorang. Kekuasaan, status gender dan agama merupakan tiga garis penanda yang menandai kehormatan seseorang dalam dunia Mediterania abad pertama. ${ }^{11}$

Penelitian terhadap simbol-simbol kehormatan seperti status gender, kekuasaan dan agama yang dilekatkan kepada para perempuan di Injil Lukas akan menjawab pertanyaan mengenai posisi perempuan dalam Injil Lukas serta signifikansi dari posisi ini. Mengingat artikel ini akan memfokuskan penelitian pada tokoh Elisabet, maka penelitian akan difokuskan pada status gender, peran-peran simbolik dan religi yang terdapat dalam kisah dan diri Elisabet, yakni kemandulannya, perannya

9. Bruce J. Malina, The New Testament World: Insights from Cultural Anthropology (Louisville: Westminster John Knox, 1993), 23.

10. Malina, The New Testament World, 23.

11. Malina, The New Testament World, 30. 
dalam janji keselamatan yakni sebagai ibu dari nabi Allah yang Mahatinggi, saksi dan penyampai nubuat tentang Mesias.

\section{Status Gender pada Elisabet}

Status seorang perempuan di daerah sekitar Mediterania lebih rendah dibandingkan laki-laki, sekalipun mereka dilahirkan dalam keluarga elite, memiliki kekayaan sendiri dan memegang jabatan keagamaan yang penting. Hal ini terjadi karena secara strata sosial mereka tidak memiliki kekuasaan di bidang politik, seperti tidak memiliki hak pilih dan menjadi pejabat pemerintah. ${ }^{12}$ Namun seorang perempuan dapat menaikkan statusnya dengan melahirkan tiga atau empat anak sebagai ahli waris yang sah bagi laki-laki, sehingga melalui ahli waris yang dilahirkannya, perempuan secara tidak langsung dapat memiliki kekuasaan dan kontrol atas properti. ${ }^{13}$ Dengan demikian, tidak memiliki anak akan membuat seorang perempuan yang telah menikah bukan hanya memiliki status sosial yang rendah, tetapi akan mengalami penghinaan dan rasa tidak aman, khususnya di keluarga suaminya.

Bagi orang Romawi, perempuan yang tidak dapat memberikan keturunan pada suaminya dapat diceraikan oleh suaminya atau suaminya dapat mengambil istri yang lain untuk meneruskan keturunan bagi dirinya dan klannya, bahkan seorang suami yang dipandang terhormat dalam masyarakat dapat melakukan hal ini. Dionisius dari Halikarnasus (60 SM-

12. Natalie Kampen, Image and Status: Roman Working Women in Ostia (Berlin: Mann, 1981), 28.

13. Kampen, Image and Status, 28-29. 
7 M) dalam Antiquitates Romanae mencatat tentang Spurius Carvilius (230 SM), seorang yang terhormat yang menceraikan istrinya karena istrinya mandul. Perceraiannya diizinkan setelah ia bersumpah di hadapan para censor bahwa ia menikah dengan tujuan untuk memiliki anak, sedangkan istrinya tidak sanggup memberikannya anak. ${ }^{14}$

Bagi orang Yahudi, kemandulan seorang perempuan seringkali dihubungkan dengan hukuman Tuhan. Tidak memiliki anak dianggap sebagai sebuah kutukan atas perbuatan jahat yang telah dilakukan (Im. 20:20-21; 2Sam. 6:23; Kej. 20:17-18; Hos. 9:11, 14). ${ }^{15}$ Hal ini dapat dilihat dari penjelasan para rabi tentang Lea dan Rahel dalam Genesis Rabbah 71:6 (abad 3M). Lea dikatakan sebagai orang benar karena ia memiliki anak, sedangkan Rahel cemburu pada kakaknya sehingga ia mendapatkan penghakiman dan penghukuman dari Allah. ${ }^{16}$ Bahkan tannaitic ${ }^{17}$ mengajarkan bahwa perempuan yang demikian dapat dianggap seakanakan ia telah mati; sebagaimana penjelasan dalam Genesis Rabbah 45:2

14. "LacusCurtius • Dionysius' Roman Antiquities - Book II Chapters 25," http://penelope.uchicago.edu/Thayer/E/Roman/Texts/Dionysius_of_Halicarnassu s/2A.html (diakses 21 Februari 2020).

15. Michael P. Closs, The Book of Mary: A Commentary on the Protevangelium of James (Victoria: FriesenPress, 2016), 9.

16. Katie Jayne Woolstenhulme, "The Role and Status of the Biblical Matriarchs In Genesis Rabbah" (Disertasi PhD, Durham University, 2017), 144.

17. Tannaitic adalah salah satu dari sekelompok sarjana Yahudi yang aktif di Palestina selama abad ke-1 dan ke-2, yang ajarannya banyak ditemukan di Misnah "Definition of Tannaitic | Dictionary.Com," https://www.dictionary.com/browse/ tannaitic (diakses 3 Maret 2020). 
yang berbunyi "It is taught (on tannaitic authority) that anyone who does not have a child, it is as if he were dead, as if he were demolished." 18

Rasa malu yang harus ditanggung oleh perempuan yang tidak dapat memiliki anak juga dirasakan oleh Elisabet. la mengakui bahwa kondisinya yang mandul adalah sebuah aib (ơveıós) di antara manusia (Luk. 1:25). Kata "ôveıóos" yang berarti "disgrace," "shame," "scandal," "abuse," "objurgation" hanya muncul sekali di PB, yakni di Lukas 1:25 ini. Kata ini memperlihatkan, "one who is covered by shame or brings disgrace on others." ${ }^{19}$ LXX secara umum menggunakan kata ini untuk menggambarkan sebuah kondisi yang disebabkan karena ketidakbenaran atau dosa manusia, termasuk ketika merujuk pada aib yang dirasakan karena kondisi yang mandul, yakni pada Rahel (Kej. 30:23). ${ }^{20}$

Penggunaan kata ơveıós di ayat 25 dalam ucapan Elisabet mengindikasikan bahwa Elisabet juga menganggap kalau kemandulannya merupakan sebuah aib yang disebabkan oleh dosanya. Aib yang demikianlah yang menjadi sumber rasa malunya di depan orang-orang. Walaupun kondisi mandul merupakan suatu aib dalam pandangan masyarakat secara umum -mengingat hal ini dianggap sebagai sebuah hukuman dari Tuhan- tetapi Lukas telah mengantisipasi hal tersebut dengan memberikan predikat "righteous before God" dan "walking in all

18. Woolstenhulme, "The Role and Status of the Biblical Matriarchs In Genesis Rabbah," 143.

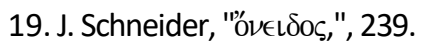

20. J. Schneider, "ov $\nu \in\llcorner\delta 0 \varsigma$, , , 239. 
the commandments and ordinances of the Lord blameless" kepada Elisabet dan Zakharia di Lukas 1:6.

\section{Benar di Hadapan Allah}

Bersama dengan suaminya, Elisabet dicatat oleh Lukas sebagai seorang yang benar di hadapan Allah, yang mengikuti semua perintah dan

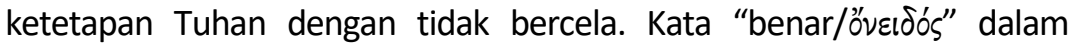
masyarakat Graeco-Roman menunjukkan adanya hubungan dengan tradisi atau kebiasaan, yang apabila disandangkan pada diri seseorang, dapat diartikan sebagai seseorang yang beradab, mengikuti adat kebiasaan, ${ }^{21}$ yang menjunjung tinggi kebiasaan dan norma perilaku. ${ }^{22}$

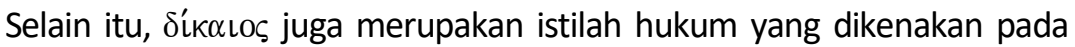
orang-orang yang menaati norma-norma hukum. Aristoteles dalam Nicomachean Ethics menyatakan, "istilah 'tidak benar' berlaku bagi mereka yang melanggar hukum dan mereka yang mengambil lebih dari haknya. Karena itu, orang yang taat hukum dan orang yang adil adalah sama-sama orang benar. Dengan demikian, 'yang benar' berarti taat hukum dan adil, dan 'tidak benar' berarti ilegal dan tidak adil.".23

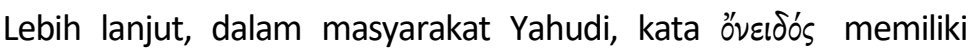
hubungan antara perilaku benar dengan rasa tanggung jawab kepada

21. Schrenk, "ơveเסós", 182.

22. BDAG, " o้veเסós" 246.

23. "Aristotle, Nicomachean Ethics, bekker page 1129a, bekker line 20," http://www.perseus.tufts.edu/hopper/text?doc=Perseus\%3Atext\%3A1999.01.005 4\%3Abekker\%20page\%3D1129a\%3Abekker\%20line\%3D20 (diakses 18 Februari 2020). 
Tuhan, yang juga menunjukkan kewajiban kepada Allah dan manusia. ${ }^{24}$ Yosefus (37-100M) dalam Antiquities of the Jews 12:43 menuliskan bahwa Simon, anak dari imam besar Onias, disebut sebagai "Simon yang benar" karena kesalehannya di hadapan Tuhan dan kebaikannya kepada orang-orang sebangsanya. ${ }^{25}$ Ini berarti aspek moral berjalan berbarengan dengan aspek religi, sehingga ketika seseorang dikatakan "benar" maka ia telah memenuhi tanggung jawab kepada Allah dan sesama. ${ }^{26}$

Pada narasi kelahiran di Injilnya, Lukas memberikan predikat "orang yang benar" pada Zakharia dan Elisabet. Kualitas diri yang dimiliki oleh Zakharia dan Elisabet di hadapan Allah ini terbukti melalui tindakan nyata dari mereka yang menaati perintah dan hukum Allah. Secara

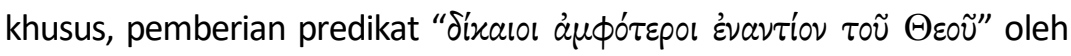
Lukas kepada Zakharia dan Elisabet menjadikan Elisabet sebagai satusatunya perempuan dalam Alkitab yang mendapatkan predikat yang demikian, yang boleh bersanding dengan Abraham, Nuh dan Ayub, serta para raja Israel dan Yehuda yang melakukan yang benar di hadapan Tuhan.

Predikat yang dikenakan oleh Lukas kepada Elisabet, yang sengaja disandingkan dengan Zakharia ini, sekaligus menjadikan Elisabet -

24. Schrenk, "öveıðós", 182.

25. Flavius Josephus, Josephus; with an English Translation by H. St. J. Thackeray, in Nine Volumes (London: Heinemann, 1926), 4.219.15, http://archieve.org/details/josephuswitheng107 joseuoft (diakses 18 Februari 2020).

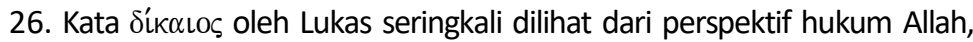
yang bersifat konkret dan dapat dilihat dalam tindakan yang nyata dan konsisten (Darrell L. Bock, Luke 1:1-9:50, BECNT [Grand Rapids: Baker Academic, 1994), 77). 
seperti halnya Zakharia- sebagai seorang yang terhormat. Dengan demikian, díxaıı merupakan simbol "common humanity" atau simbol moral yang dapat dimiliki oleh laki-laki dan perempuan untuk mendapatkan kehormatan tanpa didasarkan pada status gender yang dimiliki seseorang. Seseorang yang namanya diberikan predikat "orang benar" menunjukkan bahwa namanya memiliki asosiasi dengan status terhormat, seperti "Simon yang benar" dalam tulisan Yosefus (Ant. $12: 43) \cdot{ }^{27}$

Orang-orang Yunani kuno seringkali memberi penghormatan kepada orang-orang yang memiliki predikat sebagai "orang benar" dengan cara mendirikan monumen bagi mereka. Mereka adalah para pria yang baik, yang bertempur dengan gagah dalam peperangan, yang meneliti hukum, yang hidup secara benar, dan yang menjalankan kehidupannya untuk kepentingan dan kemakmuran bersama. ${ }^{28}$ Namun hal ini bukan hanya dilakukan untuk para pria, ada juga monumen yang didirikan untuk perempuan yang dipandang terhormat. Monumenmonumen ini dapat didirikan oleh para kerabat maupun negara, seperti monumen yang didirikan di Stratonicaea di Caria oleh kerabat Philimion untuk Philimion, seorang perempuan dari Forasa-Romawi, yang dikatakan

27. John Joseph Collins, Seers, Sibyls, and Sages in Hellenistic-Roman Judaism (New York: Brill, 2001), 243.

28. Edith Jemima Simcox, Primitive Civilizations: Or, Outlines of the History of Ownership in Archaic Communities (New York: Cambridge University Press, 2010), 431. 
sebagai seorang yang "had lived righteously and been among all worthy of the highest praise." 29

Ini memperlihatkan bahwa predikat sebagai "orang benar" menjadikan perempuan dan laki-laki menerima penghargaan yang sama sebagai seorang yang terhormat. Apalagi jika status tersebut dimiliki di hadapan Allah, orang tersebut akan mendapatkan honor di hadapan Allah, yang tentunya melebihi honor dalam pandangan manusia.

Dengan demikian, penekanan Lukas terhadap kualitas diri Zakharia dan Elisabet sebagai "orang benar di hadapan Allah," yang "melakukan semua perintah dan peraturan Allah dengan setia dan konsisten," yang adalah "orang yang terhormat," merupakan sebuah penekanan yang sangat penting. Penekanan ini dilakukan oleh Lukas dengan tujuan untuk mengantisipasi kalimat selanjutnya yang akan diungkapkannya. Kalimat

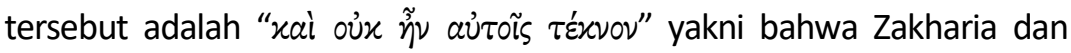
Elisabet tidak memiliki anak. Lukas hendak menekankan bahwa kondisi Zakharia dan Elisabet yang tidak memiliki anak, sama sekali tidak memengaruhi kehormatan dan kualitas diri mereka sebagai orang benar di hadapan Tuhan. ${ }^{30}$

Lebih lanjut, Allah mengangkat aib Elisabet dengan membuat Elisabet yang telah lanjut umur tersebut dapat mengandung. Mukjizat yang Allah kerjakan ini merupakan sebuah tindakan "pembalikan" terhadap kondisi Elisabet, dari yang dianggap shame menjadi honor di

29. Simcox, Primitive Civilizations, 430.

30. Bruce Malina dan Richard L. Rohrbaugh, Social Science Commentary on the Synoptic Gospels (Minneapolis: Fortress, 1993), 225. 
hadapan orang-orang. Tema "pembalikan" di Injil Lukas bukan hanya sekadar memperlihatkan honor yang Elisabet dapatkan di hadapan orangorang karena ia yang mandul dan lanjut umur telah dapat mengandung dan melahirkan, tetapi "pembalikan" terhadap perspektif masyarakat bahwa kehormatan seseorang bukanlah terletak pada kondisi fisiknya, melainkan pada ketaatannya pada firman Allah, bahwa ia seorang yang "righteous in the sight of God, walking blamelessly in all the commandments and requirements of the Lord."

\section{Peran Simbolik Pada Diri Elisabet}

Salah satu simbol yang menandai kehormatan seseorang, selain status gender, adalah kekuasaan yang dimiliki seseorang. Kekuasaan berhubungan dengan peran yang penting yang dimiliki oleh seseorang dalam masyarakat. Semakin penting peran seseorang maka semakin besar kekuasaan yang dimilikinya. Semakin besar kekuasaan seseorang, semakin besar pula kehormatan yang dimilikinya.

Pada saat kelahiran Yohanes dilihat dalam kaitannya dengan janji keselamatan dari Allah, maka Yohanes memiliki peran yang signifikan. Yohanes bukan hanya sekadar suara yang menyerukan pertobatan di padang gurun, tetapi dia adalah utusan Allah yang menyerukan agar orang-orang bertobat dan mengerti akan keselamatan yang berdasarkan pengampunan dosa melalui rahmat dan belas kasihan dari Allah melalui Yesus Kristus (1:77-78). 
Peran yang demikian signifikan dari Yohanes sebagai nabi terakhir yang menantikan kedatangan Mesias $^{31}$ membuat orang tua Yohanes memiliki peran yang juga signifikan. Kisah Elisabet bukan lagi sekadar sebuah kisah diangkatnya aib seorang perempuan mandul sehingga ia dapat melahirkan, melainkan sebuah kisah yang merefleksikan komitmen Allah kepada umat perjanjian-Nya. ${ }^{32}$ Elisabet turut berperan sebagai agen Allah dalam rancangan keselamatan-Nya bagi umat-Nya. Sebagai agen Allah, salah satu peran Elisabet adalah sebagai seorang ibu bagi nabi Allah yang Mahatinggi yang akan lahir.

\section{Ibu sebagai Simbol Patron}

Elisabet menjadi satu-satunya perempuan dalam tulisan Lukas yang memiliki predikat sebagai perempuan mandul dan juga sebagai ibu. Predikat Elisabet sebagai ibu pertama kali diberikan oleh malaikat (1:15), dan predikat ini disandingkan dengan kata "rahim." Di PB, kata "rahim" paling banyak muncul di narasi kelahiran, yakni tiga kali disandingkan dengan Elisabet $(1: 15,41,44)$ dan sekali diucapkan oleh Elisabet sebagai ucapan berkat kepada Maria (1:42). Keunikan dari cara Lukas menggambarkan Elisabet ini, menjadikan peran ibu sebagai sesuatu yang ditonjolkan oleh Lukas pada diri Elisabet. Ada tiga peran Elisabet sebagai ibu yang diperlihatkan oleh Lukas, yakni tindakannya yang menjaga "buah rahim"-nya (1:15), pengalamannya sebagai ibu bersama anak dalam

31. Bock, Luke 1:1-9:50, 187.

32. Woolstenhulme, "The Role and Status of the Biblical Matriarchs In Genesis Rabbah," 141. 
rahimnya (1:41-44), dan penamaan anak yang dilakukan oleh Elisabet (1:60).

Peran Elisabet sebagai ibu dapat memenuhi kriteria sebagai seorang patron. Gambaran seorang patron pada masa itu diperlihatkan melalui sikap dermawan yang ditunjukkannya pada kliennya. la bertindak sebagai seorang benefactor yang memberikan bantuan tanpa memikirkan pembayaran kembali, dan yang tidak mencari kepentingan sendiri. ${ }^{33}$ la akan memberikan hidupnya, menyelamatkan dan menolong kliennya tanpa pamrih. ${ }^{34}$ Bagi orang Yunani tindakan memberi yang demikian merupakan tindakan yang menyerupai tindakan dewa. ${ }^{35}$ Orang Yahudi juga seringkali menganggap Allah sebagai "the ultimate benefactor and patron of all." ${ }^{\prime 36}$

Patron yang tidak mencari keuntungan sendiri, baik sebagai Allah maupun manusia, seringkali merujuk kepada peran ayah, karena ayah dianggap mewujudkan perilaku yang terus memberi tanpa pamrih kepada anak-anaknya. la akan tetap membesarkan anak-anaknya walaupun mereka seringkali mengecewakan harapannya. ${ }^{37}$ Analogi patron sebagai

33. Alicia Batten, "God in the Letter of James: Patron or Benefactor?," New Testament Studies 50, no. 2 (2004): 261.

34. Batten, "God in the Letter of James: Patron or Benefactor?," 261.

35. Seneca, On Benefits, terj. Miriam Griffin dan Brad Inwood (Chicago: University of Chicago Press, 2011), 3.15.4.

36. Halvor Moxnes, "Patron-Client Relations and The New Community in Luke-Acts," dalam The Social World of Luke-Acts: Models for Interpretation, ed. Jerome H. Neyrey (Peabody: Hendrickson, 1991), 257.

37. Seneca, On Benefits 1.1.10. 
ayah, bersandar pada pengakuan akan kekuasaan prokreasi dan penggunaan kekuasaan tersebut yang tanpa pamrih. ${ }^{38}$

Sehubungan dengan karakteristik sebagai founder dan builder, masyarakat Mediterania menganggap prokreasi merupakan "hak istimewa laki-laki yang berakar pada asumsi bahwa 'benih' laki-laki yang menciptakan seorang anak." ${ }^{139}$ Dalam hal ini, perempuan hanya berperan dalam menyediakan rahim untuk melahirkan anak dari laki-laki pemilik 'benih' tersebut. ${ }^{40}$

Aristoteles menuliskan bahwa perempuan tidak memiliki kemampuan untuk menghasilkan semen yang sesungguhnya, ia bagaikan laki-laki yang mandul, yang kurang matang, kurang berkembang dan "cacat." ${ }^{41}$ la mengatakan, "the male provides the 'form' and the 'principle of the movement,' the female provides the body, in other words, the material." ${ }^{42}$ Dalam hal ini, perempuan berkontribusi sebagai material bagi semen untuk dapat bertumbuh. Material dianggap sebagai substansi yang kurang murni dan kurang kudus jika dibandingkan dengan semen itu sendiri. $^{43}$

38. T. R. Stevenson, "The Ideal Benefactor and the Father Analogy in Greek and Roman Thought," The Classical Quarterly 42, no. 2 (1992): 430.

39. K. C. Hanson dan Douglas E. Oakman, Palestine in the Time of Jesus: Social Structures and Social Conflicts, ed. Marla Schrader, edisi kedua (Minneapolis: Fortress, 2008), 28.

40. Hanson dan Oakman, Palestine in the Time of Jesus, 28.

41. Aristotle, Generation of Animals, terj. Arthur Leslie Peck (Cambridge Harvard University Press, 1943), 728a, http://archive.org/details/generationofanim 00arisuoft (diakses 10 Maret 2020).

42. Aristotle, Generation of Animals 729a.

43. Aristotle, Generation of Animals 728a. 
Pemahaman bahwa "benih" laki-lakilah yang menciptakan seorang anak juga dimiliki oleh orang Yahudi. Hal ini terlihat dari perkataan seorang raja dalam kitab Wisdom 7:1-2 (Good News Translation): "Like every human being, I am mortal. I am a descendant of that first man, who was made from the soil. la was conceived from the sperm of a man, in the pleasure of intercourse." ${ }^{44}$

Walaupun budaya masa itu memahami prokreasi sebagai hak istimewa laki-laki, tetapi PL memahami bahwa Allah yang memungkinkan prokreasi terjadi. PL menggambarkan hal ini dengan memperlihatkan tindakan Allah yang "membuka" rahim seorang perempuan sehingga prokreasi tersebut dapat terjadi. Rahimlah yang menjadi fokus terjadinya prokreasi. Rahim menjadi tempat Allah berkarya untuk membentuk (Mzm. 139:13-17), memberkati dan menghakimi (Kej. 20:1-18, 29:31-35, 30:22), menetapkan (Yer. 1:5), serta menghasilkan anak-anak manusia. ${ }^{45}$ Rahim yang berfungsi dalam "menghasilkan" anak manusia ini diperlihatkan dengan jelas melalui frasa "buah rahim." Anak seringkali

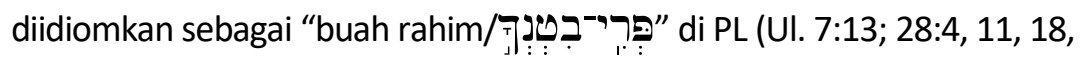

44. Sekalipun ayat ini memperlihatkan pemahaman bahwa seorang anak dianggap berasal dari "benih" laki-laki yang dibentuk dalam rahim perempuan, tetapi raja dalam ayat ini menyadari kesetaraannya dengan orang lain karena ia juga melalui proses pembentukan yang sama dalam rahim seorang perempuan. Dengan demikian, rahim menjadi simbol kesetaraan bagi seluruh umat manusia. Phyllis Trible menyatakan, "This organ is the place of human equality, an equality based in the creative work of a God who also governs life outside the womb. Social status and sexual differe nces mean nothing in the perspective of creation, and this perspective determines ethical norms and behavior" (Phyllis Trible, God and the Rhetoric of Sexuality [Philadelphia: Fortress, 1978], 36).

45. Trible, God and the Rhetoric of Sexuality, 38. 
53; 30:9; Mzm. 127:3; 132:11; Yes. 13:18; Hos. 9:16; Mi. 6:7). Penggunaan

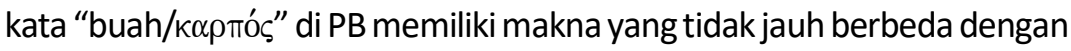
פרּרי yakni sebagai seed, fruit, product, result, profit, gain, consequence. ${ }^{46}$

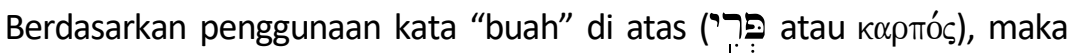
penggunaan frasa "buah rahim" menunjukkan "anak" sebagai "benih" dan "hasil" dari rahim seorang perempuan. Pemaknaan ini menjadi sebuah penghargaan terhadap rahim perempuan, yang bukan hanya sekadar sebuah material untuk tempat berkembangnya "benih" dari lakilaki -yang berarti bahwa anak dihasilkan dari laki-laki belaka- tetapi juga memiliki andil dalam menghasilkan keturunan. Dalam hal ini, ibu, melalui rahimnya, telah berperan sebagai patron, yakni sebagai founder dan builder yang ikut berperan aktif dalam proses prokreasi, yakni "menghasilkan" anak sebagai "buah rahim"-nya.

Selain itu, karakteristik patron yang lain seperti melindungi, menyelamatkan, dan memberi tanpa pamrih juga dimiliki oleh seorang ibu. Rahim menjadi tempat yang paling aman yang digunakan untuk melindungi janin yang sedang berkembang. ${ }^{47}$ Dalam hal ini, Elisabet berperan melindungi anaknya, baik ketika anaknya dalam rahim maupun dalam pengasuhannya setelah dilahirkan, yakni dengan menjauhkannya dari anggur atau minuman keras (1:15).

46. Hauck, "к $\alpha \rho \pi \varsigma_{s}, "$ 614-615.

47. Kemajuan di bidang anatomi uterus telah memperlihatkan bahwa dinding rahim sangat kuat dan elastis. la terdiri dari tiga lapisan jaringan otot, yang akan mengembang dan menjadi lebih tipis ketika seorang anak berkembang di dalamnya. "Uterus | Definition, Function, \& Anatomy," Encyclopedia Britannica, https://www.britannica.com/science/uterus (diakses 1 Maret 2020). 
Pada dasarnya pantangan untuk minum anggur atau minuman keras diberikan kepada imam (Harun dan keturunannya) ketika melayani di Kemah Suci/Bait Suci (Im. 10:8-10) dan seorang nazir yang telah bernazar (Bil. 6:1-4). Ini berarti larangan bagi Yohanes, anak Elisabet, untuk minum anggur dan minuman keras sejak dari rahim ibunya menunjukkan bahwa seumur hidupnya Yohanes adalah seorang nazir Allah yang telah dikhususkan bagi Allah. Mengingat Yohanes yang telah menjadi nazir Allah dan dipenuhi Roh Kudus sejak dari rahim ibunya, maka peran Elisabet sebagai seorang ibu dalam menjaga anak yang telah dikhususkan bagi Allah ini telah dimulai sejak anak tersebut ada dalam rahimnya.

Selain berperan dalam menjaga kekudusan anak dalam rahimnya sebagai nazir Allah, Elisabet juga memperlihatkan perannya sebagai orang tua yang menjaga identitas yang telah Allah berikan kepada anaknya melalui pemberian nama kepada anaknya. Pada masa Bait Suci kedua (516SM-70M), orang Israel cenderung menamai anaknya berdasarkan tradisi patronimik, yakni penamaan seorang anak berdasarkan nama ayahnya atau leluhur laki-laki. ${ }^{48}$ Tradisi ini disebabkan karena adanya kesulitan untuk mempertahankan genealogi dalam masa Diaspora yang dialami oleh bangsa Israel. ${ }^{49}$ Tradisi penamaan pada anak laki-laki dilakukan setelah anak tersebut disunat dengan alasan bahwa kesucian

48. Rāhēel Hakkiîî, Jewish Funerary Customs, Practices and Rites in the Second Temple Period (Leiden: BRILL, 2005), 196.

49. "A Historical View of Choosing a Jewish Name," My Jewish Learning, https://www.myjewishlearning.com/article/a-historical-view-of-choosing-a-name/ (diakses 22 Mei 2020). 
nama terjadi setelah anak tersebut termaktub ke dalam Covenant Allah dengan Israel, umat-Nya. ${ }^{50}$

Penamaan anak pertama merupakan hak istimewa yang diberikan kepada seorang ayah. ${ }^{51}$ Namun, dalam kisah penamaan Yohanes tugas ini diemban oleh Elisabet. Pada saat tetangga serta kerabatnya hendak menamai anak tersebut dengan nama Zakharia (1:59), dengan segera Elisabet menyanggah dan menyatakan bahwa anak tersebut harus dinamai Yohanes, yang berarti "LORD is a gracious giver." Sanggahan dari Elisabet yang kemudian dilegitimasi oleh Zakharia telah menghindarkan pemberian identitas yang keliru kepada Yohanes, dan berhasil menjaga identitas yang secara khusus telah diberikan oleh Allah kepada anak-Nya.

Peran-peran yang dijalankan oleh Elisabet ini memperlihatkan keaktifan Elisabet sebagai orang tua, melebihi peran Zakharia. Zakharia, sebagai seorang ayah, diperlihatkan sebagai seorang yang meragukan firman Allah dan menjadi bisu. Kondisi bisu tentunya mendatangkan "shame" jika ditinjau dari konsep purity and polluted dalam pandangan masyarakat saat itu, ${ }^{52}$ apalagi Zakharia kedapatan bisu setelah ia selesai membakar ukupan di Bait Suci (1:8). Hal ini membuat peran orang tua, layaknya seorang patron, secara aktif dijalankan oleh Elisabet.

Selain memperlihatkan peran Elisabet sebagai ibu layaknya patron, Lukas juga memperlihatkan ikatan yang kuat antara Elisabet

50. Alan Unterman, "Rites of Passage," dalam Themes and Issues in Judaism, ed. Seth Daniel Kunin (London: Cassell, 2000), 63.

51. Unterman, "Rites of Passage," 63.

52. Neyrey, "The Symbolic Universe of Luke-Acts," 279, 282. 
sebagai seorang ibu dengan Yohanes sebagai anak dalam rahimnya (1:41, 44). Layaknya ikatan yang kuat antara seorang patron dengan kliennya yang digambarkan melalui ikatan antara Allah dengan umat-Nya dan ikatan antara orang tua dengan anaknya, Elisabet juga memiliki ikatan yang kuat dengan anaknya.

Ikatan yang kuat antara ibu dan janinnya telah dipahami pada abad pertama. Teori reproduksi pada masa itu memahami bahwa pembentukan embrio dapat terjadi melalui imajinasi, emosi atau hasrat dari si ibu ketika mengandung. ${ }^{53}$ Soranus, yang sering disebut Bapak Kebidanan (98-138 M), berpendapat bahwa seorang ibu harus dalam keadaan yang sadar dan tenang selama mengandung untuk menghindari terjadinya kecacatan atau "salah bentuk" pada anak dalam kandungannya, sebab "the offspring bears some resemblance to the mother as well, not only in body but in soul." 54

Ikatan yang kuat antara ibu dan anak dalam kandungannya bukan hanya diperlihatkan melalui adanya pengaruh dari ibu ke janin, tetapi juga adanya pengaruh dari janin ke ibunya. Janin dipercaya dapat memengaruhi perasaan dan keinginan dari si ibu, seperti dalam hal "ngidam." ${ }^{55}$ Ngidam dianggap berasal dari janin, yang jika tidak dituruti akan membahayakan nyawa si ibu. ${ }^{56}$

53. Mairéad McAuley, Reproducing Rome: Motherhood in Virgil, Ovid, Seneca, and Statius (New York: Oxford University Press, 2016), 56.

54. Soranus, Soranus' Gynecology, terj. Owsei Temkin (Baltimore: Johns Hopkins University Press, 1991), 37-38.

55. Julius Preuss, Biblical and Talmudic Medicine (Lanham: Jason Aronson, 2004), 382.

56. "Yoma 82a," https://www.sefaria.org/Yoma.82a (diakses 23 Mei 2020), 
Lukas, dalam narasinya tentang Elisabet, memperlihatkan adanya ikatan yang kuat antara Elisabet dengan anak dalam rahimnya. Lukas mencatat bahwa pada saat Elisabet mendengar salam Maria, melonjaklah anak dalam rahimnya dengan penuh kegirangan dan Elisabetpun penuh dengan Roh Kudus (1:41-45). Calvin, dalam tafsiran Lukas yang ditulisnya, menyatakan bahwa kesadaran anak dalam rahim akan kehadiran Kristus dan aura kekudusan yang dirasakannya memungkinkan dimulainya gerakan Roh Kudus, tetapi perasaan tersebut bukan hanya milik anak tersebut, melainkan turut mengambil bagian pada diri ibunya. ${ }^{57}$ Roh Kudus memenuhi Elisabet dan ia mulai bernubuat.

Adanya ikatan yang kuat antara Elisabet dan anak dalam rahimnya ini semakin memperlihatkan signifikansi dari peran Elisabet sebagai ibu, yakni sebagai founder/builder dalam prokreasi, menjaga "buah rahim"-nya (1:15), mempertahankan identitas yang telah diberikan oleh Tuhan kepada anaknya melalui pemberian nama (1:60), serta dipenuhi oleh Roh Kudus dan menyampaikan nubuat yang didasarkan pada ikatan yang kuat dengan anaknya (1:41-44). Peran seorang ibu sebagai patron sangatlah menonjol dalam kisah Elisabet yang dinarasikan oleh Lukas. Simbol patron pada diri Elisabet ini berhasil menempatkan dirinya pada posisi yang setara dengan laki-laki terhormat yang biasanya menyandang gelar patron dalam masyarakat.

57. "Luke 1 Calvin's Commentaries," https://biblehub.com/commentaries/ calvin/luke/1.htm (diakses 24 Mei 2020). 
Selain peran simbolik yang dimiliki oleh Elisabet, yakni sebagai ibu yang disimbolkan sebagai patron bagi nabi Allah yang Mahatinggi, Elisabet juga memiliki peran-peran religi sebagai peran simboliknya.

\section{Peran Religi: Saksi bagi Mesias dan Penyampai Nubuat}

Berdasarkan struktur penulisan dari narasi kelahiran di Lukas 1-2, peristiwa Elisabet dipenuhi oleh Roh Kudus diperlihatkan oleh Lukas secara menonjol dan khusus. Kisah pertemuan Elisabet dan Maria pada bagian ini dapat dikatakan sebagai pusat pertemuan dari kedua tema dari narasi kelahiran, yakni kelahiran Yohanes dan kelahiran Yesus. Bauckham menyatakan bahwa kisah pertemuan Elisabet dan Maria menyebabkan persilangan atau pertemuan dari dua tema utama (kelahiran Yohanes dan Yesus) terjadi dalam pribadi dari kedua ibu ini (Elisabet dan Maria). ${ }^{58}$ Pertemuan kedua ibu yang dinarasikan tanpa kehadiran laki-laki ini memberikan posisi yang signifikan bagi kedua ibu ini.

Adapun ungkapan "dipenuhi ( $\pi \dot{\prime} \mu \pi \lambda \eta \mu \iota)$ Roh Kudus" -seperti yang dialami Elisabet- seringkali dihubungkan dengan nubuat. ${ }^{59}$ Sehubungan dengan perihal nubuat, Ju Hur dalam disertasinya " $A$ Dynamic Reading of the Holy Spirit in Luke-Acts" mengungkapkan bahwa frasa "dipenuhi Roh Kudus" oleh Lukas seringkali digunakan dalam konteks yang memperlihatkan para tokohnya sebagai orang yang menyampaikan "inspired speeches," dan melalui ucapan kenabian ini,

58. Bauckham, Gospel Women, 50.

59. Ju Hur, "A Dynamic Reading of the Holy Spirit in Luke-Acts" (Disertasi PhD, University of Sheffield, 1998), 147. 
mereka bertindak sebagai saksi bagi Yesus (Luk. 1:41-42, 67; Kis. 2:4; 4:8a, 31; 13:9-10). ${ }^{60}$ Para saksi bagi Mesias ini adalah agen Allah yang dapat dipercaya dan berotoritas, sehingga para pembaca dapat mempercayai ilham ilahi yang mereka ucapkan, sebagaimana yang Ju Hur katakan, "readers are encouraged to trust such characters and their inspired speeches, and to anticipate that their prophetic utterances would be fulfilled." ${ }^{\prime 1}$

Berdasarkan pemahaman tentang penggunaan ungkapan "dipenuhi Roh Kudus" dan berdasarkan struktur narasi kelahiran yang menonjolkan pertemuan kedua ibu (1:39-45), maka tidaklah berlebihan jika dikatakan bahwa Lukas secara khusus hendak menonjolkan peranan Elisabet sebagai satu-satunya perempuan yang secara eksplisit dikatakan "dipenuhi Roh Kudus." Ungkapan ini telah menempatkan Elisabet sebagai perempuan yang kesaksiannya dapat dipercaya dan berotoritas karena ia adalah agen dari Allah dan Anak Allah yang Mahatinggi. la adalah orang pertama di PB yang digunakan oleh Allah sebagai saksi bagi Sang Mesias, yaitu Penyelamat yang telah lama dinanti-nantikan oleh umat Allah. Dialah orang pertama yang mengungkapkan bahwa bayi dalam rahim Maria, yakni Yesus, adalah Tuhan dan Pribadi yang akan membuat apa yang telah Allah janjikan menjadi genap/sempurna $\left(\tau \in \lambda \in i(\omega \sigma \iota \varsigma) . .^{62}\right.$ Dalam hal ini, penggunaan kata "dipenuhi oleh Roh Kudus" oleh Lukas kepada

60. Hur, "A Dynamic Reading of the Holy Spirit in Luke-Acts," 147.

61. Hur, "A Dynamic Reading of the Holy Spirit in Luke-Acts," 148.

62. $\tau \in \lambda \epsilon \epsilon \omega \sigma \iota \varsigma$ berarti perfection, fulfillment of a promise (BDAG, " $\tau \in \lambda \in \epsilon^{\prime} \omega \sigma \iota \varsigma, "$ 997). Kata ini hanya digunakan sekali oleh Lukas merujuk pada eksekusi akhir atau penyempurnaan dari janji Allah (Bock, Luke 1:1-9:50, 139). 
Elisabet telah menonjolkan peranan Elisabet sebagai seorang saksi sekaligus sebagai seorang yang menjalankan tugas kenabian.

Peranan Elisabet sebagai saksi bagi Mesias sangatlah istimewa mengingat masyarakat Yahudi pada umumnya menganggap perempuan tidak layak untuk menjadi seorang saksi. Yosefus dalam Antiquities of the Jews 4:219 menuliskan syarat-syarat bagi seorang saksi, yakni: "But let not a single witness be credited, but three, or two at the least, and those such whose testimony is confirmed by their good lives. But let not the testimony of women be admitted, on account of the levity and boldness of their sex." ${ }^{163}$

Bagi Yosefus, perempuan seringkali sembrono dalam perkataannya, sehingga tidak dapat menjadi saksi yang baik. Sedangkan dalam budaya Romawi, perempuan masih diizinkan untuk menjadi saksi dalam pengadilan. Namun demikian, kesaksian tersebut lebih merupakan pembelaan diri dari perempuan tersebut atas kasus yang menimpanya. Apabila kasus yang ada bukanlah kasus dari perempuan itu sendiri, perempuan tersebut tidak dapat menjadi saksi bagi orang lain, dengan alasan bahwa hal tersebut dapat beresiko menimbulkan rasa malu karena dapat melanggar norma kesopanan dan etika seksual. ${ }^{64}$

Dengan kata lain, dalam budaya Yahudi maupun Romawi, menjadi saksi merupakan hak dan kewajiban seorang laki-laki, sedangkan perempuan kurang layak untuk menjadi saksi. Namun Lukas justru

63. Josephus Antiquities of the Jews 4.219.

64. Richard A. Bauman, Women and Politics in Ancient Rome (London: Routledge, 1994), 50. 
memperlihatkan profil Elisabet sebagai seorang perempuan yang berperan sebagai saksi yang kredibel dan berotoritas karena kesaksiannya didasarkan pada pekerjaan Roh Kudus yang "memenuhi"-nya. Peranan Elisabet sebagai saksi ini menjadi menonjol bukan hanya karena ia adalah seorang saksi perempuan, tetapi juga karena ia adalah saksi yang pertama bagi Mesias.

Selain peran religinya sebagai saksi bagi Mesias, Elisabet juga memiliki peran sebagai penyampai nubuat tentang Mesias. Bagi orang Israel, nabi (נְבְיא) maupun nabiah (נְבְיאה) adalah orang yang dipanggil dan dipilih oleh Tuhan, yang berbicara atas nama-Nya untuk mengingatkan, menegur, menghibur, mengajar dan memberitahukan sesuatu yang akan datang. ${ }^{65}$ Nabi dan nabiah yang berbicara atas nama Tuhan juga mengekspresikan kedekatan seseorang dengan Tuhan, sehingga

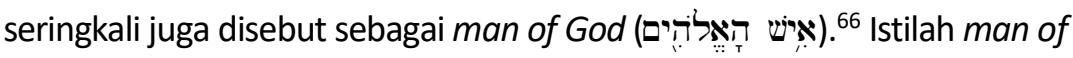
God ini juga diberikan kepada para pemimpin yang besar seperti Musa (UI. 33:1), Daud (Neh. 12:24, 36), Samuel (1Sam. 9:6) dan secara khusus Elisa (29 kali). Ada juga tokoh-tokoh terkemuka yang disebut sebagai nabi, seperti Abraham (Kej. 20:7) dan Harun (Kel. 7:1). Para nabi seringkali dipandang sebagai pemimpin dan tokoh terkemuka sehingga membuat jabatan nabi adalah jabatan yang terhormat dalam masyarakat (1Sam. 9:6), bahkan jabatan yang cenderung diperebutkan dan diidamkan pada masa itu. ${ }^{67}$

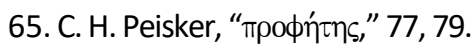

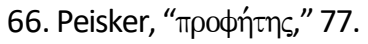

67. Jerome H. Neyrey, "Despising the Shame of the Cross: Honor and Shame in the Johannine Passion Narrative," Semeia 68 (1994): 116. 
Sekalipun Elisabet tidaklah menyandang jabatan sebagai seorang nabiah secara permanen, tetapi Elisabet diperlihatkan sebagai seorang yang menjalankan "tugas kenabian" melalui "inspired speech" dari Roh Kudus yang diucapkannya. Sama halnya dengan nabi yang dipenuhi oleh Roh Kudus dalam menyampaikan nubuat dari Tuhan, begitu pula Elisabet dipenuhi oleh Roh Kudus untuk menyampaikan nubuat tentang Tuhan. Ia menjadi salah satu perempuan yang mengemban peran yang sangat penting dalam sejarah keselamatan.

\section{Kesimpulan}

Berdasarkan simbol-simbol kehormatan yang diberikan kepada Elisabet, berupa statusnya sebagai perempuan dengan predikat "benar di hadapan Allah," peran ibu sebagai simbol patron, dan peran religinya sebagai saksi dan penyampai nubuat, dapatlah disimpulkan bahwa Lukas memosisikan Elisabet secara positif dalam Injilnya. Elisabet adalah seorang perempuan yang mengakui bahwa Tuhan telah mengangkat aibnya di hadapan orang-orang dan menjadikannya ibu bagi seorang anak yang adalah nabi Allah yang Mahatinggi. Status yang memalukan yang disandang oleh Elisabet sebagai seorang perempuan mandul telah diangkat oleh Tuhan. Identifikasi Lukas tentang status Elisabet yang mandul tidaklah bertujuan untuk merendahkan Elisabet melainkan untuk memperlihatkan cara Allah bekerja dalam sejarah keselamatan, yakni dengan "membalikkan" status seseorang dari yang hina menjadi mulia.

Posisi yang terhormat juga disandang oleh Elisabet melalui peran sebagai ibu dan peran-peran religi yang diberikan kepadanya. Peran- 
peran ini diperlihatkan secara lebih menonjol dan positifjika dibandingkan dengan peran Zakharia, suaminya. Elisabet lebih berperan aktif sebagai orang tua, layaknya patron, dalam mengandung "buah rahim," menjaga "buah rahim-"nya, menamai anaknya sesuai dengan perintah Tuhan, dan memiliki ikatan yang kuat dengan anak dalam rahimnya. Selain itu, peranan Elisabet juga diperlihatkan melalui simbol-simbol religi yang terhormat, yakni sebagai saksi Tuhan dan penyampai nubuat tentang Tuhan. la adalah perempuan pertama yang menjadi saksi bagi Mesias, yang menjalankan "tugas kenabian" dengan mengucapkan "inspired speech" tentang Mesias. Bahkan dibandingkan Zakharia, Elisabet yang lebih dahulu diperlihatkan sebagai seorang yang dipenuhi Roh Kudus dan "bernubuat."

Signifikansi dari penonjolan posisi Elisabet oleh Lukas ini adalah untuk memperlihatkan bahwa perempuan dapat mengemban peran yang penting, bahkan peran yang sangat penting dalam sejarah keselamatan. Perempuan pun dipilih dan dipakai oleh Tuhan sebagai agen penting dalam rancangan keselamatan-Nya, sebagaimana yang Witherington katakan, "Luke presents these women (Elizabeth and Mary) not only as witnesses to the events surrounding the births of John and Jesus, but also as active participants in God's Messianic purposes." 68

Berbagai simbol kehormatan yang disematkan kepada Elisabet dengan jelas memperlihatkan posisi yang positif yang Lukas berikan kepada perempuan, bahkan terkesan lebih positif dan menonjol daripada

68. Ben Witherington III, Women in the Earliest Churches (New York: Cambridge University Press, 1991), 134. 
laki-laki. Penonjolan posisi perempuan yang positif dan terhormat ini telah membuat perempuan menjadi fokus perhatian dalam Injil Lukas karena telah menaikkan perempuan dari posisi yang lebih rendah menjadi setara dengan laki-laki.

Perempuan, seperti halnya laki-laki, dapat memperoleh kehormatan melalui predikat "orang benar," dapat berperan sebagai patron, dan dapat dipilih dan dipakai oleh Tuhan untuk menjadi saksi bagi Dia dan penyampai nubuat tentang Dia, bahkan secara istimewa dalam sejarah keselamatan.

Pada akhirnya, posisi perempuan yang sangat positif ini memperlihatkan bahwa perempuan dapat tampil kompeten dan kredibel dalam segala ranah, yakni di ranah privat sebagai seorang ibu, sekaligus di ranah publik sebagai seorang yang bersaksi bagi Tuhan, baik bersaksi dengan perkataan, mengucapkan inspired speech, maupun dengan kehidupannya yang benar di hadapan Tuhan.

\section{Daftar Pustaka}

\section{Buku}

Bauckham, Richard. Gospel Women: Studies of the Named Women in the Gospels. Grand Rapids: Eerdmans, 2002.

Bauer, Walter. A Greek-English Lexicon of the New Testament and Other Early Christian Literature, diedit oleh Frederick William Danker. Edisi Ketiga. Chicago: University of Chicago Press, 2001.

Bauman, Richard A. Women and Politics in Ancient Rome. London: Routledge, 1994.

Bock, Darrell L. Luke 1:1-9:50. Baker Exegetical Commentary on the New Testament. Grand Rapids: Baker Academic, 1994.

Closs, Michael P. The Book of Mary: A Commentary on the Protevangelium of James. Victoria: FriesenPress, 2016. 
Collins, John Joseph. Seers, Sibyls, and Sages in Hellenistic-Roman Judaism. New York: BRILL, 2001.

deSilva, David A. Honor, Patronage, Kinship \& Purity: Unlocking New Testament Culture. Downers Grove: IVP Academic, 2000.

Eriksen, Thomas Hylland. Antropologi Sosial dan Budaya: Sebuah Pengantar. Maumere: Ledalero, 2009.

Evans, Mary J. Woman in the Bible: An Overview of All the Crucial Passages on Women's Roles. Downers Grove: Intervarsity Press, 1984.

Hakklîî, Rāhēl. Jewish Funerary Customs, Practices And Rites In The Second Temple Period. Leiden: BRILL, 2005.

Hanson, K. C., dan Douglas E. Oakman. Palestine in the Time of Jesus: Social Structures and Social Conflicts, diedit oleh Marla Schrader. Edisi kedua. Minneapolis: Fortress, 2008.

Hur, Ju. "A Dynamic Reading of the Holy Spirit in Luke-Acts." Disertasi PhD. University of Sheffield, 1998.

Ihromi, T. O. "Kata Pengantar." Dalam Pokok-Pokok Antropologi Budaya, viixxv. Jakarta: Pustaka Obor, 2013.

Kampen, Natalie. Image and Status: Roman Working Women in Ostia. Berlin: Mann, 1981.

Kittel, Gerhard dan Gerhard Friedrich, eds. Theological Dictionary of the New Testament, vol. II. Grand Rapids: Eerdmans, 1965.

Kittel, Gerhard dan Gerhard Friedrich, eds. Theological Dictionary of the New Testament, vol. III. Grand Rapids: Eerdmans, 1966.

Kittel, Gerhard dan Gerhard Friedrich, eds. Theological Dictionary of the New Testament, vol. V. Grand Rapids: Eerdmans, 1968.

Malina, Bruce J. dan Richard L. Rohrbaugh. Social Science Commentary on the Synoptic Gospels. Minneapolis: Fortress, 1993.

Malina, Bruce J. The New Testament World: Insights from Cultural Anthropology. Louisville: Westminster John Knox, 1993.

McAuley, Mairéad. Reproducing Rome: Motherhood in Virgil, Ovid, Seneca, and Statius. New York: Oxford University Press, 2016.

Moxnes, Havor. "Patron-Client Relations and The New Community in LukeActs." Dalam The Social World of Luke-Acts: Models for Interpretation, diedit oleh Jerome H. Neyrey, 241-270. Peabody: Hendrickson, 1991.

Neyrey, Jerome H. "The Symbolic Universe of Luke-Acts: They Turn the World Upside Down." Dalam The Social World of Luke-Acts: Models 
for Interpretation, diedit oleh Jerome H. Neyrey, 271-304. Peabody: Hendrickson, 1991.

Preuss, Julius. Biblical and Talmudic Medicine. Lanham: Jason Aronson, 2004.

Seim, Turid Karlsen. "Feminist Criticism." Dalam Methods for Luke, diedit oleh Joel B. Green, 42-73. New York: Cambridge University Press, 2010.

Seneca. On Benefits. Diterjemahkan oleh Miriam Griffin dan Brad Inwood. Chicago: University of Chicago Press, 2011.

Simcox, Edith Jemima. Primitive Civilizations: Or, Outlines of the History of Ownership in Archaic Communities. New York: Cambridge University Press, 2010.

Soranus. Soranus' Gynecology. Diterjemahkan oleh Owsei Temkin. Baltimore: Johns

Trible, Phyllis. God and the Rhetoric of Sexuality. Philadelphia: Fortress, 1978.

Unterman, Alan. "Rites of Passage." Dalam Themes and Issues in Judaism, diedit oleh Seth Daniel Kunin, 56-80. London: Cassell, 2000.

Witherington III, Ben. Women in the Earliest Churches. New York: Cambridge University Press, 1991.

Woolstenhulme, Katie Jayne. "The Role and Status of the Biblical Matriarchs In Genesis Rabbah." Disertasi PhD. Durham University, 2017.

\section{Jurnal}

Batten, Alicia. "God in the Letter of James: Patron or Benefactor?" New Testament Studies 50, no. 2 (2004): 257-72.

Neyrey, Jerome H. "Despising the Shame of the Cross: Honor and Shame in the Johannine Passion Narrative." Semeia 68 (1994): 113-37.

Stevenson, T. R. "The Ideal Benefactor and the Father Analogy in Greek and Roman Thought." The Classical Quarterly 42, no. 2 (1992): 421-36.

\section{Website}

"A Historical View of Choosing a Jewish Name." My Jewish Learning. https://www.myjewishlearning.com/article/a-historical-view-ofchoosing-a-name/ (diakses 22 Mei 2020). 
"Aristotle, Nicomachean Ethics, bekker page 1129a, bekker line 20." http://www.perseus.tufts.edu/hopper/text?doc=Perseus\%3Atext\% 3A1999.01.0054\%3Abekker\%20page\%3D1129a\%3Abekker\%20line \%3D20 (diakses 18 Februari 2020).

"Definition of Tannaitic | Dictionary.Com." Www.Dictionary.Com. https:// www.dictionary.com/browse/tannaitic (diakses 3 Maret 2020).

"LacusCurtius • Dionysius' Roman Antiquities-Book II Chapters 1-29." http://penelope.uchicago.edu/Thayer/E/Roman/Texts/Dionysius_of _Halicarnassus/2A.html (diakses 21 Februari 2020).

"Luke 1 Calvin's Commentaries." https://biblehub.com/commentaries/ calvin/luke/1.htm (diakses 30 Maret 2020)

"Uterus | Definition, Function, \& Anatomy." Encyclopedia Britannica. https://www.britannica.com/science/uterus (diakses 1 Maret 2020). "Yoma 82a." https://www.sefaria.org/Yoma.82a (diakses 23 Mei 2020). Aristotle. Generation of Animals. Diterjemahkan oleh Arthur Leslie Peck. Cambridge Harvard University Press, 1943. http://archive.org/ details/generationofanim00arisuoft (diakses 10 Maret 2020).

Flavius Josephus. Josephus; with an English Translation by H. St. J. Thackeray, in Nine Volumes. London: Heinemann, 1926.

http://archieve.org /details/josephuswithengl07joseuoft (diakses 18 Februari 2020). 